\title{
Impact of Long-Term Citrate Dialysate Use on Survival in Haemodialysis Patients
}

\author{
Guillaume Séret $^{\mathrm{a}} \quad$ Pierre-yves Durand $^{\mathrm{b}}$ Wael El-Haggan ${ }^{c}$ Frédéric Lavainne ${ }^{\mathrm{d}}$ \\ Muriel Menanteau ${ }^{\mathrm{e}}$ Angelo Testa $^{\mathrm{f}}$ Victorio Menoyo $^{\mathrm{b}}$ on behalf of Medial Study \\ Group (France)
}

${ }^{a}$ Centre ECHO, Pôle Santé Sud, Le Mans, France; ${ }^{b}$ Centre ECHO, Hôpital Bretagne Atlantique, Vannes, France;

${ }^{c}$ Centre ECHO, Hôpital de Laval, Laval, France; d Centre ECHO, Pole Santé Atlantique, Nantes, France; ${ }^{e} \mathrm{Centre} \mathrm{ECHO,}$

Pharmacie à Usage Intérieur, Nantes, France; ${ }^{f}$ Centre ECHO, Hôpital privé du Confluent, Nantes, France

In December 6, 2018, the French National Agency for the Safety of Medicinal Products sent a national warning message focused on the citrate-based dialysate used for haemodialysis [1]. This alert followed data presented at the Nephrology, Dialysis and Transplantation French Society 2018 annual meeting. These data, based on the French Dialysis Registry [2] (REIN), showed an increase in mortality, up to $40 \%$, in patients exposed to citrate-based dialysate.

The use of citrate increases gradually due to improved session tolerance with acetate-free haemodialysis [3-6]. It is also known that citric acid leads to changes in ionized calcium level during the haemodialysis session, with an increased risk of hypocalcaemia [7]. Several side effects have been identified, such as muscle spasms, cramps and arterial hypotension [8]. Several studies have evaluated the tolerance of citrate exposure without showing severe complications [9-11]. Nevertheless, follow-up periods were short, and data about cardiovascular events was lacking.

We conducted a retrospective study, issue from the MEDIAL ${ }^{\mathrm{TM}}$ database, to determine the impact of citrate exposure on the mortality of haemodialysis patients. MEDIAL ${ }^{\mathrm{TM}}$ is a French database including 7,000 current patients and a total of more than 850,000 haemodialysis sessions-year recorded.

We reviewed data of 1,169 incident patients who had started haemodialysis between January 1, 2014 and December 31,2018 . On the basis of the citrate exposure level, we identified a cohort of 409 patients divided into 2 groups: Group A $(0-10 \%$ of all sessions, $n=121)$ and Group B (75-100\% of all sessions, $n=$ 288). Patients not receiving citrate were exposed to standard acetate. Patients transferred to other dialysis units, or other treatment modalities were excluded, as were patients for whom comorbidities were not reported. The median of followup was $23 \pm 18$ months.

Group A and B did not show any significant difference in the proportion of women $(\mathrm{A}=39 \%, \mathrm{~B}=41 \% ; p=0.74)$, central catheter use $(A=17 \%, B=16 \% ; p=0.59)$, neither in the frequency of the major comorbidities: dyslipidaemia $(A=54 \%, B=56 \% ; p=0.4)$, hypertension $(A=90 \%, B=85 \% ; p=0.07)$, heart failure $(\mathrm{A}=17 \%, \mathrm{~B}=19 \% ; p=0.35)$, coronary artery disease $(\mathrm{A}=18 \%, \mathrm{~B}=24 \%$; $p=0.1)$, stage 3 or 4 peripheral arterial disease $(A=9 \%, B=9 \% ; p=0.69)$, cerebrovascular disease $(A=14 \%, B=16 \% ; p=0.51)$, cardiac arrhythmia $(\mathrm{A}=27 \%, \mathrm{~B}=22 \% ; p=$ $0.41)$ and ongoing cancer $(A=14 \%, B=13 \%$; $p=0.75)$. Diabetes mellitus was more frequent in group $\mathrm{B}(\mathrm{A}=17 \%, \mathrm{~B}=30 \%$; $p=$ $0.001)$, and the population was older $(\mathrm{A}=$ $60.8 \pm 16.6$ years, $B=67.4 \pm 14.7$ years; $p<$ $0.001)$, with a higher average $\mathrm{BMI}(\mathrm{A}=25 \pm$ $\left.5.6 \mathrm{~kg} / \mathrm{m}^{2}, \mathrm{~B}=26.7 \pm 6.4 \mathrm{~kg} / \mathrm{m}^{2} ; p=0.01\right)$. Regarding laboratory parameters, only the mean values for serum albumin were different $(38.8 \pm 5.2 \mathrm{~g} / \mathrm{L}, \mathrm{B}=36 \pm 4.6 \mathrm{~g} / \mathrm{L} ; p<$ $0.001)$. The average values of calcemia, phosphoremia, parathyroid hormone, bicarbonatemia, haemoglobin, CRP and Kt/V were comparable between the 2 groups.

There is no significant difference in survival between groups A and B for all dialysis modalities combined (Fig. 1).

In conclusion, our study does not show an increased risk of mortality in haemodialysis patients with citrate-based dialysate, despite higher comorbidities in the citrate exposure group.

\section{Acknowledgements}

None.

This work was carried out within the institution "Association Echo-Dialyse".

\section{karger@karger.com \\ www.karger.com/bpu \\ (C) 2019 S. Karger AG, Base}

Karger
Dr. Guillaume Séret

Centre ECHO, Pôle Santé Sud

Pôle Santé Sud, 34 rue de Guetteloup

FR-72000 Le Mans (France)

E-Mail gseret@echo-sante.com 
Fig. 1. Survival comparison of haemodialysis patients with citrate-based dialysate (Group B) and dialysate without citrate (Group A). ns, non-significant.

\section{Statement of Ethics}

No approval was required.

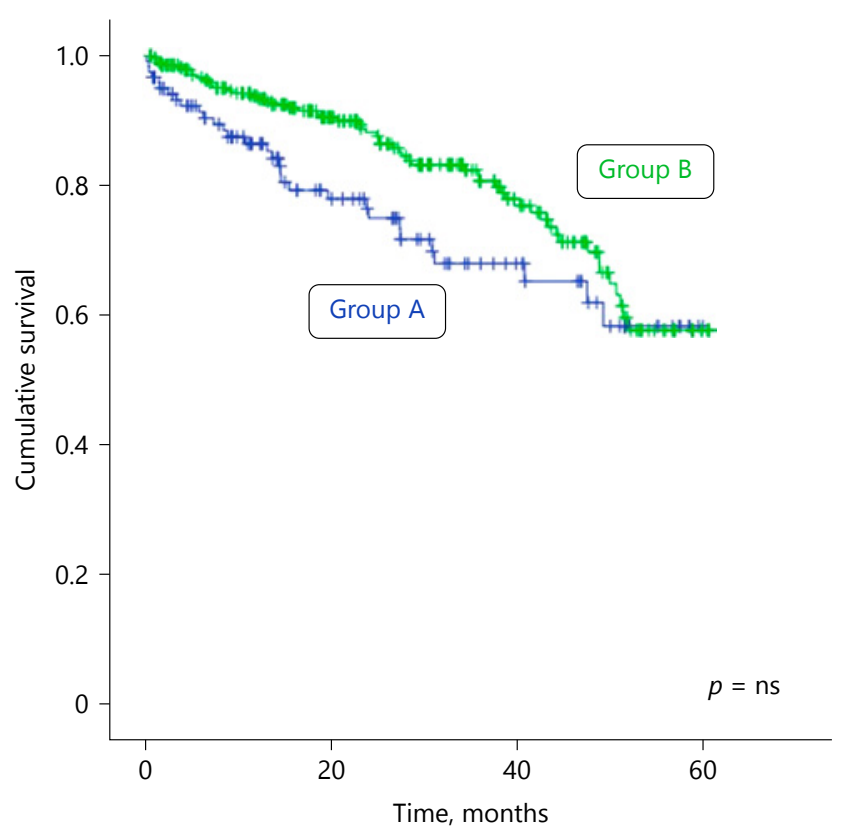

\section{Disclosure Statement}

The authors have no conflicts of interest to declare.

\section{Funding Sources}

The study did not receive any funding.

\section{References}

1 Utilisation du dialysat au citrate : Réunion des parties prenantes à l'ANSM sur une éventuelle surmortalité liée à l'utilisation du dialysat au citrate - Communiqué - ANSM : Agence nationale de sécurité du médicament et des produits de santé [Internet]. [cited 2019 Mar 12]. Available from: https://ansm.sante.fr/Sinformer/Communiques-CommuniquesPoints-presse/Utilisation-du-dialysat-au-citrate-Reunion-des-parties-prenantes-a-1ANSM-sur-une-eventuelle-surmortaliteliee-a-l-utilisation-du-dialysat-au-citrateCommunique.

2 Couchoud C, Stengel B, Landais P, Aldigier JC, de Cornelissen F, Dabot C, et al. The renal epidemiology and information network (REIN): a new registry for end-stage renal disease in France. Nephrol Dial Transplant. 2006 Feb;21(2):411-8.

3 Gabutti L, Lucchini B, Marone C, Alberio L, Burnier M. Citrate- vs. acetate-based dialysate in bicarbonate haemodialysis: consequences on haemodynamics, coagulation, acid-base status, and electrolytes. BMC Nephrol. 2009 Mar;10(1):7.

4 Daimon S, Dan K, Kawano M. Comparison of acetate-free citrate hemodialysis and bicarbonate hemodialysis regarding the effect of intra-dialysis hypotension and post-dialysis malaise. Ther Apher Dial. 2011 Oct;15(5): 460-5.

5 Molina Nuñez M, de Alarcón R, Roca S, Álvarez G, Ros MS, Jimeno C, et al. Citrate versus acetate-based dialysate in on-line haemodiafiltration. A prospective cross-over study. Blood Purif. 2015;39(1-3):181-7.

6 Mercadal L, Franck JE, Metzger M, Yuan W, Kolko A, Monnet E, et al. Improved survival associated with acetate-free haemodialysis in elderly: a registry-based study. Nephrol Dial Transplant. 2015 Sep;30(9): $1560-8$.

7 Grundström G, Christensson A, Alquist M, Nilsson LG, Segelmark M. Replacement of acetate with citrate in dialysis fluid: a randomized clinical trial of short term safety and fluid biocompatibility. BMC Nephrol. 2013 Oct; 14(1):216.

8 Durand PY, Nicco C, Serteyn D, Attaf D, Edeas M. Microbiota Quality and Mitochondrial Activity Link with Occurrence of Muscle Cramps in Hemodialysis Patients using Citrate Dialysate: A Pilot Study. Blood Purif. 2018;46(4):301-8.

9 Pizzarelli F, Cerrai T, Dattolo P, Ferro G. Online haemodiafiltration with and without acetate. Nephrol Dial Transplant. 2006 Jun; 21(6):1648-51.

10 Panichi V, Fiaccadori E, Rosati A, Fanelli R, Bernabini G, Scatena A, et al. Post-dilution on line haemodiafiltration with citrate dialysate: first clinical experience in chronic dialysis patients. ScientificWorldJournal. 2013 Dec; 2013:703612.

11 Schmitz M, Loke O, Fach B, Kalb K, Heering PJ, Meinke D, et al. Effects of citrate dialysate in chronic dialysis: a multicentre randomized crossover study. Nephrol Dial Transplant. 2016;31(8):1327-34. 